DOI: $10.21802 /$ artm.2019.2.10.88.

УДК 616.314-083:528.315-38

\title{
ВИВЧЕННЯ МОРФОМЕТРИЧНИХ ХАРАКТЕРИСТИК КАПІЛЯРНОЇ СІТКИ ПІСЛЯ ДВОМІСЯЧНОЇ СУБКУТАННОЇ ІМПЛАНТАЦІЇ ПОРИСТОГО ВОЛОКНИСТОГО МАТРИКСУ
}

\author{
А.В. Пантус \\ Івано-Франківський національний медичний університет, кафедра хірургічної стоматології, \\ м. Івано-Франківськ, Украӥна, \\ ORCID ID: 0000-0002-5245-8836, \\ e-mail: zlatoslava2@ukr.net
}

Резюме. Проблема, що стоїть перед тканинною інженерією, полягає в тому, щоб оптимізувати виділення, розмноження і диференціювання клітин, сконструювати матрикси або системи доставки, сприяючи підтримці, координації регенерації тканин у трьох вимірах. Одним із важливих критеріїв, який повинен враховуватись при конструюванні матриксу - його здатність підтримувати стабільну гемодинаміку всередині та навколо каркасу. Мета дослідження - експериментально оцінити характер розвитку судинної сітки після двомісячної субкутанної імплантації біополімерного волокнистого матриксу.

Дослідження проводилось на 20 лабораторних тваринах (кролі), які були поділені на 2 групи. Першій групі порівняння - 10-ом тваринам - проводилось оперативне втручання, яке включало формування «кишені» в підшкірній клітковині та накладання швів. Другій групі - 10-ом тваринам - проводилась підшкірна імплантація біополімерного матриксу в ділянку спини між лопатками. Для дослідження брали 9 сегментів: один центрально розташований і по 4 сегменти $з$ парацентральної та 3 периферичної зон.

Статистичне опрацювання результатів проводили в програмному забезпеченні Microsoft Excel 2016, що входить до пакету програмного забезпечення Microsoft Office 2016 (Microsoft).

Отримані результати свідчать про відсутність як гострої, так і хронічної реактивної запальної інфільтрації, а також як гострої, так і хронічної реакції відторгнення імплантата як чужорідної субстанції у імплантованій ділянці тварини. Створений нами волокнистий матрикс завдяки своїй гігроскопічності та пористості створює своєрідний місток для проростання та розвитку капілярної сітки.

Ключові слова: біополімер, біоімплантат, судинна сітка.

Вступ. На даний час у медицині та біоінженерії з кожним роком зростає інтерес до біополімерів. Матеріали в тканинній інженерії для створення біоімплантатів повинні володіти спектром спеціальних властивостей і надавати інженерним або мікроінженерним конструкціям характеристик, властивих живим тканинам, а саме: здатність до самовідновлення, здатність змінювати будову і властивості у відповідь на фактори навколишнього середовища [1]. Проблема, що стоїть перед тканинною інженерією, полягає в тому, щоб оптимізувати виділення, розмноження i диференціювання клітин, сконструювати каркаси або системи доставки, сприяючи підтримці, координації регенерації тканин у трьох вимірах $[2,3]$. Одним із важливих критеріїв, який повинен враховуватись при конструюванні матриксу - це його здатність підтримувати стабільну гемодинаміку всередині та навколо каркасу. Стабільність гемодинаміки та відповідно життєздатність тканин буде залежати передусім від характеру розвитку капілярної сітки всередині скафолда $[4,5]$.

Мета дослідження. Експериментально оцінити характер розвитку судинної сітки після двомісячної субкутанної імплантації біополімерного волокнистого матриксу.

Матеріали та методи дослідження. Для проведення досліджень було використано розробле- ний нами волокнистий матрикс із гранул 100 \% чистого полілактиду. Матрикс розробляли методом фазового розділення полімеру. Товщина волокнистого матриксу в середньому становила 30 мм. Діаметр волокон становив від 4 мкм до 10 мкм (рис. 1, рис. 2).

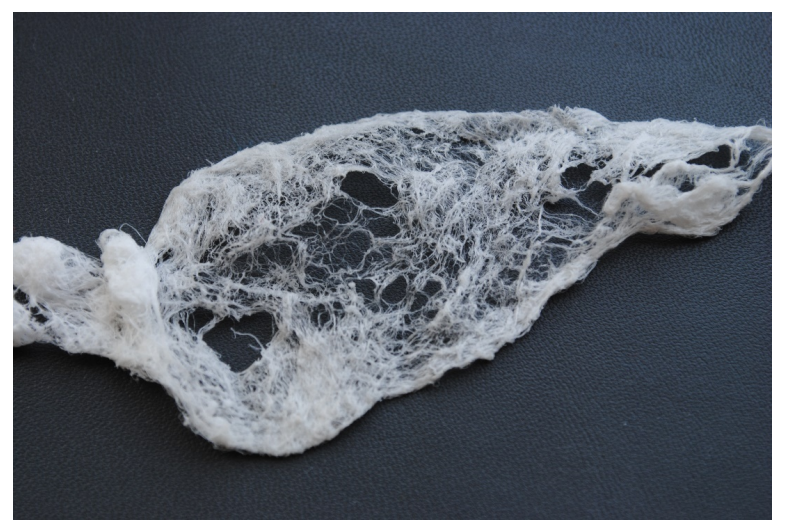

Рис. 1. Волокна біополімерного матриксу. Об. 10, ок. 10

Вище вказані матрикси піддавались гаммастерилізації. Герметично запаковані в подвійну упаковку для стерилізації скафолди рівномірно вкладались під електронний пучок 3 енергією частинок 4 
мегаелектронвольт (МеВ) і протяжністю імпульсів 4,5 мікросекунд (мкс). Кожен пакет «Medicom» стандартизований EN 868-5, ISO 11140-1, ISO 11607-1, в який був запакований полімер товщиною 0,6мм. При опроміненні кількість імпульсів змінювалась від 4 до 70.

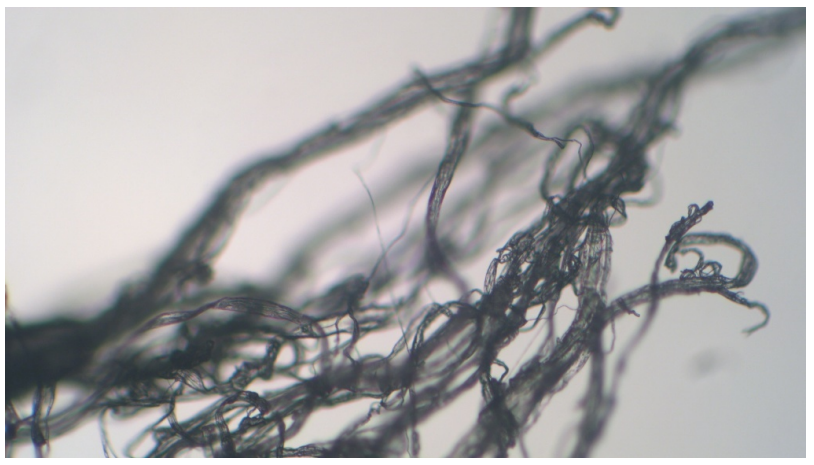

Рис. 2. Волокна біополімерного матриксу. Об. 10, ок. 10

Стерилізація відбувалась за наступними параметрами: частота роботи прискорювача складала 250 Гц, максимальна енергія електронів становила $5 \mathrm{MeB}$, максимальна потужність пучка становила 5 кВт, тривалість імпульсів 4,5 мкс, імпульсний струм до $1,5 \mathrm{~A}$, потужність гальмуючого випромінювання на відстані 1м від мішені становила - 104 Р/сек. Доза опромінення об'єкта становила до 50 кГр з розрахунку об'єму та щільності матеріалу. Згідно з нормами максимально допустима доза 50 кГр при максимальній енергії електронів 5 МеВ. Обробка електронами з енергією менше $10 \mathrm{MeB}$ не викликала ядерних трансмутацій, тобто не призводила до виникнення радіоактивних ізотопів і не створювала залишкового радіаційного фону об'єкту. Після стерилізації біополімерні матрикси хірургічним шляхом імплантувались під шкіру лабораторної тварини. Дослідження проводилось на 20 лабораторних тваринах (кролі), які були поділені на 2 групи. Першій групі порівняння: 10-ом тваринам проводилось оперативне втручання, яке включало формування «кишені» в підшкірній клітковині та накладання швів. Другій групі: 10-ом тваринам проводилась підшкірна імплантація біополімерного матриксу в ділянку спини між лопатками. Через 2 місяці хірургічним шляхом матрикс разом із прилеглими тканинами видалявся з тіла тварини.

Всі маніпуляції з експериментальними тваринами проводили 3 дотриманням правил відповідно до «Європейської конвенції про захист хребетних тварин, що використовуються для дослідних та інших наукових цілей» [6].

Для здійснення загального гістологічного дослідження матрикс з оточуючими тканинами розсікали взаємноперпендикулярними розрізами на 25 однакових сегментів. Для дослідження брали 9 сегментів: один центрально розташований i по 4 сегменти 3 парацентральної та 3 периферичної зон. Отримані ділянки імпланту фіксували у $10 \%$ розчині нейтрального формаліну $(\mathrm{Ph}-7,0)$. Час фіксації складав 24 години. У подальшому шматочки досліджуваних органів поміщали у висхідну батарею спиртів для дегід- ратації, далі у хлороформ, суміш хлороформ-парафін (1:1), парафін (при температурі $37^{\circ} \mathrm{C}$ ). Після парафінової препідготовки шматочки заливали в парафін. Виготовлення серійних парафінових зрізів товщиною 4-6 мкм проводилося на санному мікротомі. Забарвлення препаратів здійснювалося гематоксиліном і еозином [7].

Гістологічні препарати досліджувались світлооптично на мікроскопі Leica DME під різними збільшеннями об'єктива й окуляра. Морфометричні показники визначали за допомогою системи для отримання мікроскопічних зображень гістологічних мікропрепаратів (мікроскоп Leica DME та цифрова фотокамера "Nikon P5100") та програми аналізу зображень Image Tool 2.0 for Windows на кафедрі патоморфології та судової медицини Івано-Франківського національного медичного університету. Статистичне опрацювання результатів проводили в програмному забезпеченні Microsoft Excel 2016, що входить до пакету програмного забезпечення Microsoft Office 2016 (Microsoft).

Результати дослідження. При патоморфологічному дослідженні кровоносної системи периферичної ділянки імплантованих волокнистих полімерних матриксів двомісячного терміну в сполучній тканині виявляються здебільшого дрібні судини площею поперечного перерізу $2458,87 \pm 3,23$ мкм $^{2}$, 3 тонкими стінками товщиною $6,87+3,76$ мкм, вистелені ендотелієм, здебільшого заповнені еритроцитами. Згідно 3 даними морфометричного дослідження, на 1 переріз судини припадає 79913,72+3,12 мкм² площі сполучної тканини.

Слід відзначити, що в перикапсулярних зонах зростає щільність судинного русла, що становить $75080,86+4,23$ мкм² площі сполучної тканини на один переріз судини.

У парацентральних ділянках волокнистого каркасу в товщі жирової тканини візуалізуються різного калібру судини (рис. 3). Здебільшого судини дрібного калібру типу капілярів, площею поперечно-

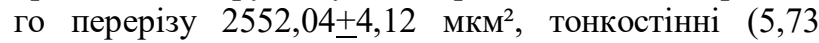
мкм). На одному переріз судини становить 58769,85+3,98 мкм² площі тканини.

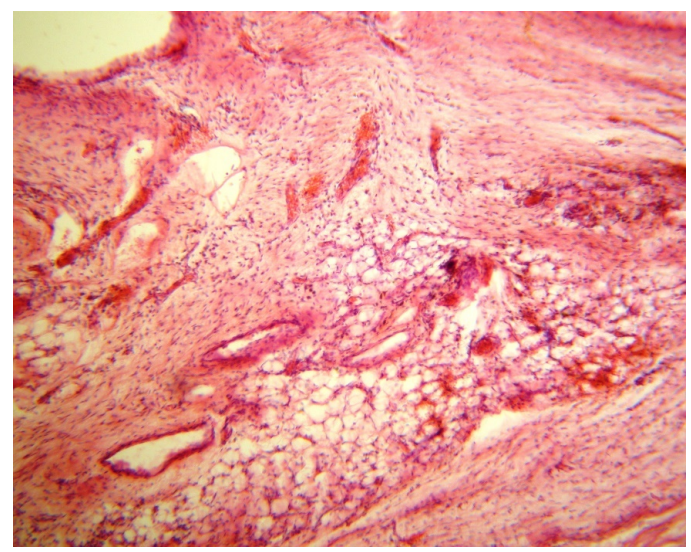

Рис. 3. Судини сполучної тканини парацентральної зони. Забарвлення: гематоксилін та еозин. Об. 10, ок. 10 
У даних судинах візуалізується тонка базальна мембрана, тонкий шар сполучнотканних волокон дозовні від останньої. Зсередини судини вистелені ендотелієм. Ядра ендотеліоцитів витягнуті вздовж периметру судин, 3 гомогенним хроматином, чіткою каріолемою. Цитоплазма ендотеліальних клітин вистеляє базальну мембрану, світла, еозинофільна, гомогенна. Просвіт даних капілярів здебільшого заповнений еритроцитами. Місцями виявляються судини більшого калібру за типом артеріол і дрібного калібру артерій. У стінці візуалізується шар циркулярно розташованих у кілька рядів гладких міоцитів із дещо витягнутими та циркулярно розташованими ядрами. Гладкі міозити компактно розташовані. Просвіт даних судин незначний, ядра ендотеліоцитів менш витягнуті порівняно з капілярами. У просвіті відзначається незначна кількість еритроцитів.

Вогнищево в сполучній тканині між окремими групами волокон імплантавізуалізується лімфоцитарно-макрофагальна інфільтрація помірної інтенсивності (рис. 4). Поміж клітинами візуалізуються судини, просвіти яких заповнені еритроцитами, проте лейкостазів і пристінкового розташування інтраваскулярних лейкоцитів не виявлено.

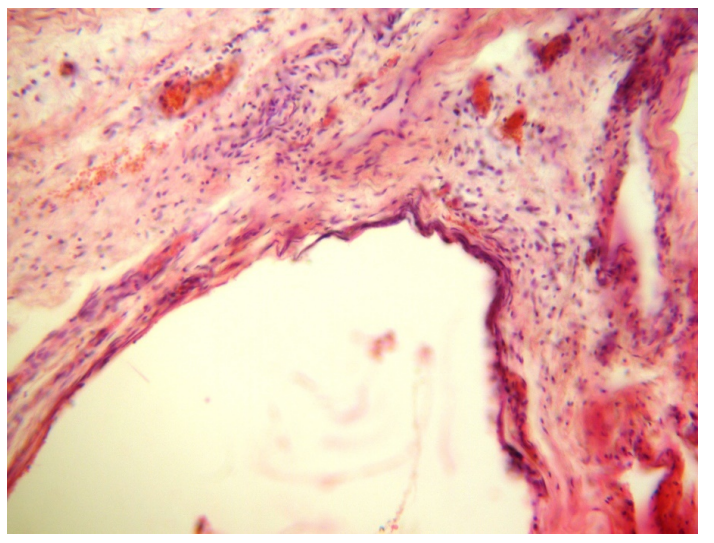

Рис. 4. Лімфоцитарно-макрофагальна інфільтрація. Забарвлення: гематоксилін та еозин. Об. 10, ок. 10

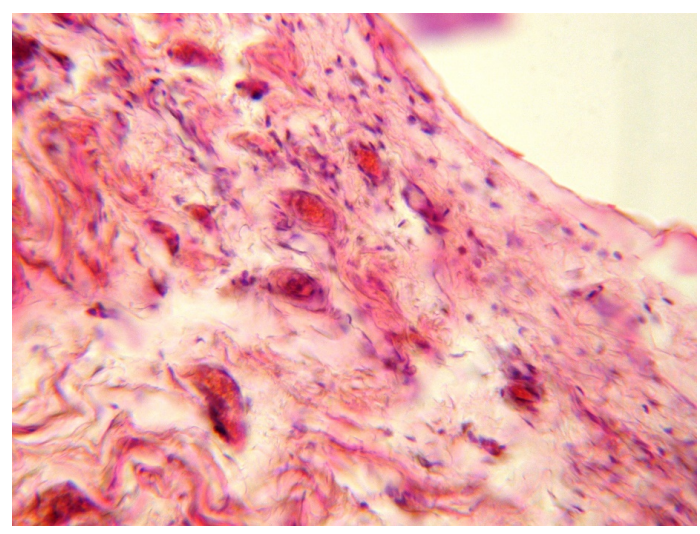

Рис. 5. Судини сполучної тканини центральної зони. Забарвлення: гематоксилін та еозин. Об. 10, ок. 10
При патоморфологічному дослідженні центральних зон імплантів двомісячнго терміну в сполучній тканині в просторах між волокнами наявні різного калібру судини (рис. 5).

Судини, які розташовуються в сполучній тканині, за даними морфометричного дослідження, мають середню площу поперечного перерізу $3268,46 \pm 4,75$ мкм²$^{2}$, товщиною стінки 4,95+0,14 мкм. Серед даних судин одні більш дрібні з ядрами ендотеліоцитів овальної форми, з чіткою базальною мембраною, у просвіті невелика кількість еритроцитів. Поряд із цим, візуалізуються судини більш крупного калібру за типом венул із тонкими стінками, заповнені еритроцитами, з витягнутими вздовж базальної мембрани ядрами. Загалом, на один переріз судини припадає 53247,58+3,33 мкм² площі сполучної тканини.

У тварин контрольної групи морфометричний аналіз проводили 3 фрагментів сполучної тканини взятих 3 різних ділянок післяопераційної зони. Площа поперечного перерізу судин у цій групі становила $2188,67 \pm 4,32$ мкм $^{2}$, а на один переріз судини припадало 49345,65+3,13 мкм² площі сполучної тканини.

Аналіз та обговорення результатів. На основі проведених досліджень встановлено, що стан капілярної сітки, яка оточує та пронизує волокна біополімерного матриксу, практично не відрізнявся від тварин контрольної групи. Невелика різниця стосувалась показників площі поперечного перерізу судин та показників площі сполучної тканини на 1 переріз судини. В основній групі дані показники були дещо більшими, ніж у контрольній, що може бути пов'язано з більш посиленим синтезом сполучної тканини та адаптаційними механізмами, спрямованими на виведення продуктів гідролізу полімеру. Аналіз периферичної, парацентральної та центральної зон імплантованого волокнистого матриксу в тварин основної групи показав зростання площі поперечного перерізу судин від периферії до центру, що може свідчити про активне протікання біосинтетичних процесів у центральних відділах волокнистого матриксу, а відсутність ознак руйнування капілярів свідчить про відсутність накопичення продуктів гідролізу матеріалу і його своєчасне виведення із центральної зони. Про це також свідчить наявність венул у центральній частині матриксу. Натомість відбувається зменшення показників площі сполучної тканини на 1 переріз судин від периферії до центру.

\section{Висновки:}

1. Відсутність значної кількості нейтрофільних лейкоцитів, збільшеної кількості макрофагів i лімфоцитів свідчить про відсутність як гострої, так і хронічної реактивної запальної інфільтрації, а також як гострої, так і хронічної реакції відторгнення імплантат як чужорідної субстанції в імплантованій ділянці тварини.

2. Створений нами волокнистий матрикс завдяки своїй гігроскопічності та пористості створює своєрідний місток для проростання та розвитку капілярної сітки. 
References:

1. Olesova VN, Dovbnev VA, Evstratov OV, Zveryaev AG, Zuev MD, Lesnyak AV i dr. Preimuschestva vremennyih nesyemnyih frezerovannyih i polimerizovannyih plastmassovyih protezov na implantatah. Klinichiskie issledovaniya. 2013; 1:25-26 [inRussian].

2. Andryushechkina TN, Berchenko GN, Gioeva YUA, Zoryan EV, Atrushkevich VG. Vliyanie kompleksnyih antigomotoksicheskih preparatov na tkani parodonta $\mathrm{v}$ aktivnom periode ortodonticheskogo lecheniya: eksperimentalno-morfologicheskoe i klinicheskoe issledovanie. Klinicheskaya stomatologiya. 2015; 4:42-49 [inRussian].

3. Balin VN, Balin DV, Iordanishvili AK, Muzyikin MI. Osteostimuliruyuschee deystvie ksenogennogo kostnogo materiala na reparativnyiy osteogenez (eksperimentalno-morfologicheskoe issledovanie). Stomatologiya. 2015; 94(2):5-9 [in Russian].

4. Hayashi CH, Gudino CV, Gibson FC, Genco CA. Review: pathogen-induced inflammation at sites distant from oral infection: bacterial persistence and induction of cells pecific innate immune inflammatory pathways. Mol. Oral. Microbiol. 2010; 5(25):305-316.

5. Deev RV, Isaev AA, Kochish AYU, Tihilov RM. Kletochnyie tehnologii $\mathrm{V}$ travmatologii $\mathrm{i}$ ortopedii: putirazvitiya. Kletochnaya transplantologiya i tkanevaya injeneriya. 2016; 3(6):22-33 [in Russian].

6. Poriadok provedennia naukovymy ustanovamy doslidiv, eksperymentiv na tvarynakh. Ofitsiinyi visnyk Ukrainy. Ofits. vyd. 2012; 24:82 [in Ukrainian].

7. Bahrii MM, Dibrova VA, Popadynets $\mathrm{OH}$, Hryshchuk MI Metodyky morfolohichnykh doslidzhen: monohrafiia. Vinnytsia: Novaknyha. 2016. P.328 [in Ukrainian].

УДК 616.314-083:528.315-38

ИЗУЧЕНИЕ МОРФОМЕТРИЧЕСКИХ ХАРАКТЕРИСТИК КАПИЛЛЯРНОЙ СЕТКИ ПОСЛЕ ДВУХМЕСЯЧНОЙ СУБКУТАННОЙ ИМПЛАНТАЦИИ ПОРИСТОГО ВОЛОКНИСТОГО МАТРИКСА

\section{А.В. Пантус}

Ивано-Франковский национальный медицинский университет, кафедра хирургической стоматологии, 2. Ивано-Франковск, Украина, ORCID ID: 0000-0002-5245-8836, e-mail: zlatoslava2@ukr.net

Резюме. Проблема, стоящая перед тканевой инженерией, заключается в том, чтобы оптимизировать выделение, размножение и дифференцировку клеток, сконструировать матрикс или системы доставки, способствуя поддержанию, координации регенерации тканей в трех измерениях. Одним из важных критериев, который должен учитываться при конструировании матрикса - его способность поддерживать стабильную гемодинамику внутри и вокруг каркаса. Цель исследования - экспериментально оценить характер развития сосудистой сетки после двухмесячной субкутаннои имплантации биополимерного волокнистого матрикса.

Исследование проводилось на 20 лабораторных животных (кролики), которые были разделены на 2 группы. Первой группе сравнения - 10 животным проводилось оперативное вмешательство, которое включало формирования «кармана» в подкожной клетчатке и наложения швов. Второй группе - 10 животным - проводилась подкожная имплантация биополимерного матрикса в область спины между лопатками. Для исследования брали 9 сегментов: один центрально расположен и по 4 сегмента с парацентральной и из периферической зон.

Статистический анализ результатов осуществлено с помощью компьютерных программ Microsoft Exel и Statistica 5.5 (Multiple Regression) с использованием методов вариационной статистики, корреляции.

Полученные результаты свидетельствуют об отсутствии как острой, так и хронической реактивной воспалительной инфильтрации, а также как острой, так и хронической реакции отторжения имплантата как чужеродной субстанции в имплантированном участке животного. Созданный нами волокнистый матрикс, благодаря своей гигроскопичности и пористости, создает своеобразный мостик для прорастания и развития капиллярной сетки.

Ключевые слова: биополимер, биоимплантат, сосудистая сетка.

\section{UDC 616.314-083:528.315-38 \\ STUDY OF THE MORPHOMETRIC FEATURES OF CAPILLARY NETWORK IN THE EARLY STAGES OF POROUS FIBER MATRIX IMPLAN- TATION}

\author{
A.V. Pantus \\ IvanFranko National Medical University, Department of \\ Surgical Dentistry, Ivano-Frankivsk, Ukraine, \\ ORCID ID: 0000-0002-5245-8836, \\ e-mail: zlatoslava2@ukr.net
}

\begin{abstract}
The problem facing tissue engineering is to optimize the selection, reproduction and differentiation of cells, to construct matrices or delivery systems, contributing to the maintenance, coordination of tissue regeneration in three dimensions. One of the important criteria that must be taken into account when constructing a matrix is it sability to maintain astablehemo dynamics inside and around the frame work. Currently the interest in biopolymers in bioengineering and medicine is increasing progressively. The materials used in tissue engineering are expected to have some special features and supply engineer and microengineer constructions with characteristics that living tissues have, as follows: the ability of self-repair; the ability of changing anatomy and properties in response to environmental factors.
\end{abstract}


The purpose of the study is to experimentally evaluate the development of the vascular net after two months of subcutaneous implantation of the biopolymer fibrous matrix.

The research was carried out on 20 lab animals (rabbits), which were divided into two groups. The first group: surgical intervention was performed to 10 animals, which included the creation of the pocket in the subcutaneous adipose tissue and suturing. The second group: the implantation of the biopolymer matrix into the area between the shoulder blades was performed to 10 animals.

The month after the matrix with the underlying tissues was removed. It was divided into 25 parts for histological examination. 9 segments were chosen for analysis: the one from centrally located area, four segments from precentral and four ones from peripheral zones.

The histological slides were examined lightoptically with the help of the microscope Leica DME with different magnifications. The morphometric features were analyzed using the system for taking microscopic pictures of histological samples (microscope Leica DME and digital camera Nikon P5100) and by using the program Image Tool 2.0 for Windows. The research were conducted at the Department of Pathomorphology and Legal Medicine of Ivano-Frankivsk National Medical University.
Statistical analysis was performed with the aid of PC programs Microsoft Exel and Statistica 5.5 (Multiple Regression) using the methods of variation statistic and correlation.

By using a freezing microtome the slides 30-50 $\mathrm{nm}$ were made, then were dehydrated in alcohols of different concentrations, soaked in methyl salicylate and fixed in polystyrene. After wards, the slides were examined with the microscope MPS-6.

The analysis of the peripheral, paracentral and central zone of the implanted possession of the matrix in the main group is determined by the plane of the crosssection of the vessels from the periphery to the center, which can lead to the active flow of biosynthetic processes in the central departments of power. material and its preferences from the central zone. This is also evidenced by the presence of venules in the central part of the matrix. The location is based on a decrease in the area of connective tissue in 1 section of the court from the periphery to the center.

The results display the absence of acute or chronic inflammatory infiltration as well as no transplantation rejection. The fiber matrix made by us, creates a peculiar bridge for germination and development of capillary network due to its hygroscopicity and sponginess. vascularmesh.

Keywords: biopolymer, bioimplant,

Стаття надійшла в редакцію 02.04.2019 р. 